\title{
GEOLOGICAL AND MAGNETIC SUSCEPTIBILITY MAPPING OF MOUNT GIOUCHTA (CENTRAL CRETE)
}

\author{
Kokinou E. ${ }^{1}$, Kamberis E. ${ }^{2}$, Sarris A. ${ }^{3}$ and Tzanaki I. ${ }^{1}$ \\ ${ }^{1}$ Department of Natural Resources and Environment, Technological Educational Institute Crete, 3 Romanou \\ Str.Chalepa,Chania,Crete, GR 73133 -Greece,ekokinou@chania.teicrete.gr \\ ${ }^{2}$ Hellenic Petroleum (Exploration and Exploitation of Hydrocarbons Division), 199 Kifissias Av., 15124 \\ Maroussi, Athens - Greece,ekamperis@hellenic-petroleum.gr \\ ${ }^{3}$ Laboratory of Geophysical-Satellite Remote Sensing \& Archaeo-environment, Institute for Mediterranean \\ Studies, Foundation for Research and Technology-Hellas, P.O. Box 119, 74100 Rethymnon, \\ Crete-Greece, asaris@ret.forthnet.gr
}

\begin{abstract}
Giouchta Mt. is located south of Heraklion city, in Crete. It is an N-S trending morphological asymmetric ridge, with steep western slope whilst the eastern slope represents a smoother relief, composed of Mesozoic limestone and Eocene-lower Oligocene flysch sediments of the Gavrovo-Tripolis zone. The present study focuses on the geological structure of Mt. Giouchta. Field mapping and tectonic analysis is performed for this purpose. The dominant structures are contractional in nature, deformed by normal faulting related to the extensional episodes initiated in Serravallian times. The strain pattern in the area is revealed from strain analysis. It is inferred that the orientation of the stress field in the area has changed several times: the N-S, stress field which was dominant during Late Serravallian times changed to NE-SW (in Late Serravallian? - Early Tortonian) and subsequently to WNW-ESE (Early to Middle Tortonian) to become NW-SE in Late Tortonian. This orientation changed also during the Quaternary times trending from NW-SE (Early Pleistocene) to ENE-WSW (Middle Pleistocene-Holocene).

In addition to the above, surface soil samples were collected in the wider area of mount Giouchta and they were analyzed in order to determine the magnetic susceptibility. GIS techniques were used for mapping the spatial distribution of the geological features and the magnetic measurements on the topographic relief of the area. Statistical analysis techniques were also applied in order to investigate the relation of faulting and magnetic susceptibility. Maps representing the spatial distribution of the above measurements were created by using appropriate interpolation algorithms.
\end{abstract}

Key words: Gavrovo-Tripolis zone, fault scarp, Heraklion basin, Southern Greece.

\section{Introduction}

Crete is situated as an emergent high in the forearc of the subduction system of the African and the Aegean plates. The curved Hellenic outer-arc runs from the Greek mainland to the west towards the western coast of Turkey to the east. Several submarine troughs oriented perpendicular to the arc-parallel plate boundary subdivide the arc into an island chain. Crete is situated in the outermost apex of the outer-arc. The topography of Crete is characterized by a highly mountainous landscape sug- 
gesting rather young and rapid uplift. A fast rise of the island is also indicated by Neogene marine deposits of Middle Miocene to early Late Pliocene age that have been uplifted up to several hundreds of meters above the present sea-level (Meulenkamp et al., 1988, 1994). A large number of surface faults underline the essential input of intense tectonic activity on both the surface itself and the landscape evolution (Bonnefont, 1971; Angelier, 1979).

The present work aimed towards a better understanding of the geological conditions in the mountainous area of Giouchta Mt. (Fig.1A) in the Archanes municipality. For this purpose a geological and tectonic survey were conducted in the summer of 2008. Surface soil samples were collected and analyzed in order to determine their magnetic susceptibility and investigate any possible correlation with the geological features. The digital terrain model, structural elements, sedimentary and geophysical data were combined in a GIS. GIS enabled not only the easy visualization of the results but it also contributed to the spatial analysis and correlation among the various geological features.

\section{The study area}

The study area (Fig. 1B) belongs to the Gavrovo-Tripolis zone. According to Brun (1956) and Aubuin (1959) the External Hellenides s.l. in Western Greece (Pindos, Gavrovo-Tripolis, Ionian and preApulian zones), consist of a series of sub-parallel, north-south trending tectonostragraphic zones including several east-dipping thrust sheets and west verging folds. The Gavrovo-Tripolis zone represents a stable shallow carbonate dominated platform (Dercourt, 1964). The Gavrovo- Tripolis sediments include Middle Triassic to Upper Eocene limestones and Eocene to Lower Oligocene flysch (Fleury, 1980). The permanent shallow-water sediments (Late Jurassic to Latest Cretaceous) appear as a distinct unit affected by successive regressive episodes (Bernier and Fleury, 1980). According to Alexander et al. (1980) this unit structurally underlies Pindos thrust sheets.

The carbonate sequences (Fig. 2) exposed in Giouchta Mt. and located in the northern and southern part of the mountain, comprise Jurassic-Lower Cretaceous (J-K) light grey to grey black, medium bedded to massive, karstic, limestones. The dolomitization decreases from base to top. The central part of Giouchta Mt. is dominated by Upper Cretaceous (Ks.k), grey-black medium-thick bedded, bituminus and dolomitic limestones. Flysch of Upper Eocene-Oligocene belonging to the GavrovoTripolis zone is detected in the northeastern flank of the mountain, comprising alterations of schists and sandstones with small layers of grey calcareous turbidites.

Fassoulas (2001) characterized Giouchtas Mt. as a horst occurred by two antithetic faults that bound the limestones. Based on the slope map presented in Figure 1C, we can further add that this mountain comprise an asymmetric anticline or tectonic horst. This is because slopes of about 80 degrees dominate in the western site of Giouchta Mt. and up to 60 degrees in the eastern part.

\section{Methodology}

A detailed stratigraphic and tectonic mapping was conducted in the study area (covering about 16 $\mathrm{Km}^{2}$ ) in the summer of 2008. Field data was firstly correlated with the Geological map of Greece (1:50000), Epano Archanes Sheet (IGME). Tectonic analysis has been done using FP Tectonics.

Samples were collected from various areas within a depth of $0-15 \mathrm{~cm}$ below the surface. GPS coordinates (in EGSA 87 system) were determined at each sampling site in order to be in correlated with the available topographic data. Each of the soil samples was mixed, air-dried, disaggregated and sieved retaining the fraction smaller than $2 \mathrm{~mm}$ in size in order to reduce the biasing effect of air, water and pebbles. Since our samples were of unknown density, mass specific measurements seemed 


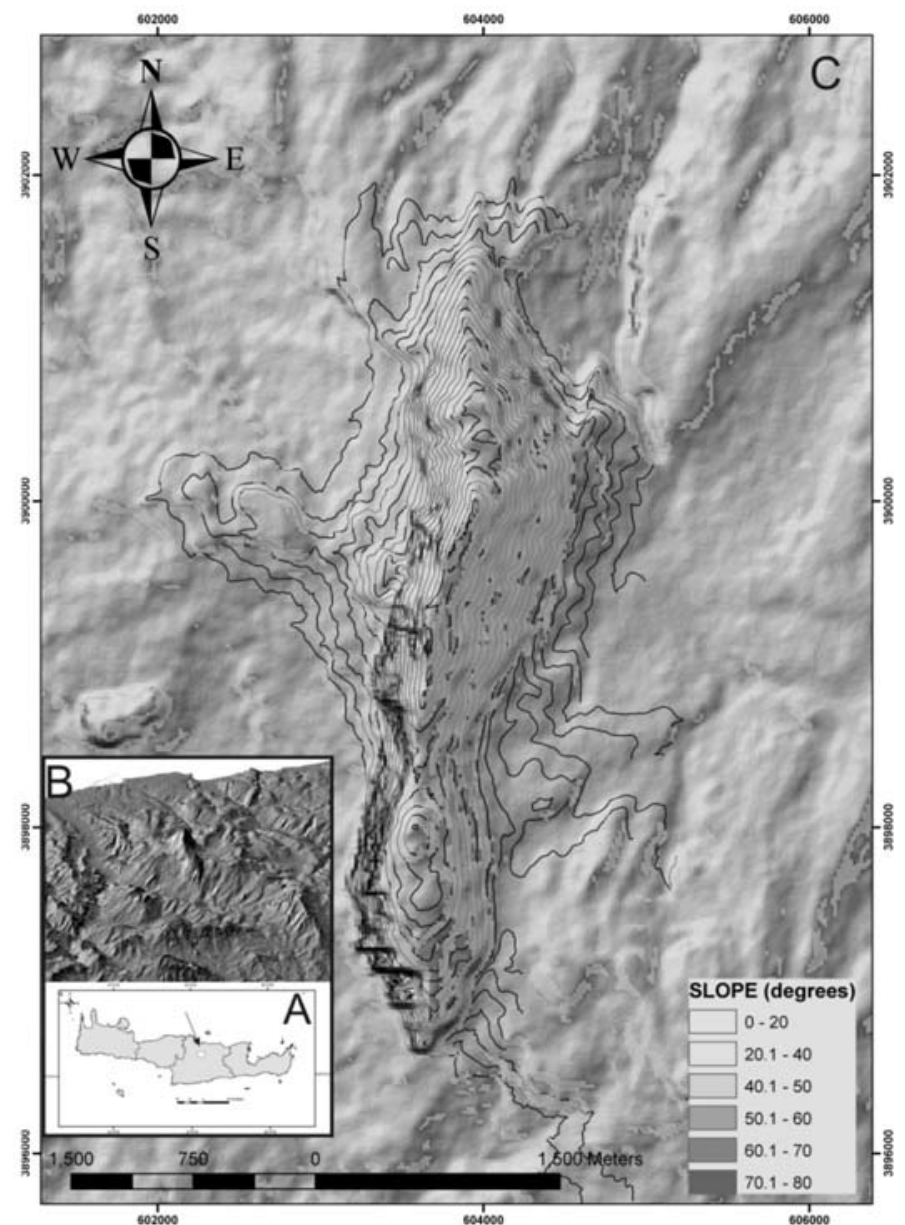

Fig. 1: (A): Location of the study area; (B): Topographic relief showing the wide area of study with the main structural features; (C): a slope map produced from $20 \mathrm{~m}$ digital elevation data.

to be more appropriate compared with those based on specific volume. Bartington MS2 susceptibility meter was employed for measuring magnetic susceptibility in two frequencies. A sample of $10 \mathrm{~cm}^{3}$ tightly packed Manganese Carbonate powder $\left(\chi=99.2 \times 10^{-6} \mathrm{emu} / \mathrm{gr}\right)$ was used for calibration of the instrument. The consistency of the instrument calibration was checked by measuring the susceptibility of the calibration sample in the beginning and end of the measuring session. Samples were weighted and the subsequent susceptibility measurements in both frequencies were multiplied by a factor $\mathrm{w}_{\mathrm{f}}=(10 /$ weight of sample $)$ in order to normalize our measurements for a mass of $10 \mathrm{gr}$. The contribution of the plastic container was measured for 10 pieces and the average value was subtracted from all measurements.

Digitization techniques and GIS were applied for mapping representation of the data. The digital elevation model was created by the digitization of the topographic map contours (1:5000 scale maps), while the cell size of the digital elevation model was $20 \mathrm{~m}$. Gridding of the magnetic susceptibility was carried out using the inverse distance weighted method. Buffer zones of variable distances were used to calculate the proximity of the particular topographic features with magnetic properties. 


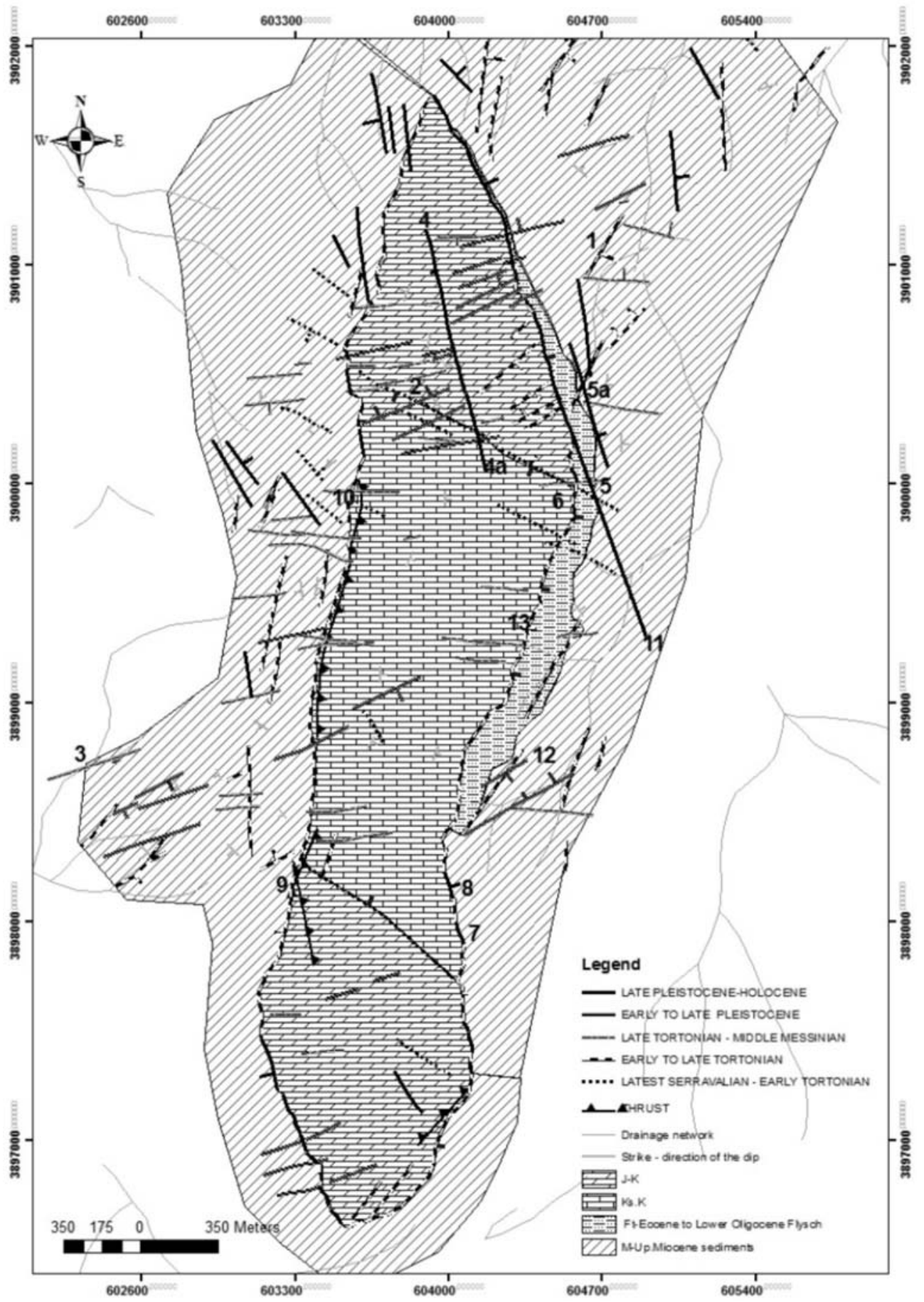

Fig. 2: Geological map of the study area. J-K: Jurassic - Lower Cretaceous limestones, Ks.K: Upper Cretaceous limestones, Ft: Eocene to Lower Oligocene Flysch, M-Up. Miocene sediments. Numbers represent locations of special interest (comments in the text). 


\section{Results}

\section{Structural Data}

Cross-cutting relationships between the members of the different fault systems, morphotectonic features and overprinting criteria were used in order to classify, both compressional and extensional structures and related stress field patterns. According to Angelier (1979) reverse and strike slip faults on Crete are rare, small and caused by brief compressional events. In this study compressional structures recorded in J-K present the NE-SW trending general strike of the alpine deformation (southeastern flank of Giouchta Mt), resulting from the NW trending stress field (Figs. 2, 3). Another contraction structure, located in the western flank of Giouchta Mt., witnesses a reverse movement in the Middle (?) - Late Serravallian (about 13.0 Ma) (Figs. 2, 3). This structure might be related to contraction tectonics inferred by Benda et al. (1974) for the eastern Mediterranean and Crete. The above-mentioned stress fields and the related compressional tectonics are also supported by other authors and might be associated to the crustal thickening continued on Crete probably until some weakly-defined time in the middle Miocene (e.g. Mercier et al., 1989; Jolivet et al., 1994, 1996; ten Veen and Postma, 1999). Giouchta Mt. demonstrates a contraction feature (asymmetric anticline) related to the above-mentioned stress fields (Fig. 3). Following the contraction tectonics successive, distinct, extensional episodes took place creating six fault generations considered herein.

Normal fault systems are indicated in Giouchta Mt, i.e. Late Serravallian, Latest Serravallian (?) to Early Tortonian, Early to Middle Tortonian, Late Tortonian, Early Pleistocene and finally Middle Pleistocene to Recent, depicting the above-mentioned tectonic episodes. The results of the tectonic fault plain analysis, the fault strike classification and the correlation to similar studies in the central and eastern Crete, are shown in detail in Figure 3.

The first group includes, roughly E-W trending, in the order km-scale faults active until Late Serravallian times (Fig. 2). Angelier (1979) supported that large normal block faulting probably became in Serravallian times. Fault surfaces and kinematical indicators of these faults are not well preserved. However, overprinting relationships (based on fault intersections and stratigraphic boundaries) indicate that might correspond to the group "A" (Fig. 3, column 3) determined in the central and the eastern part of Crete by Benda et al., (1974), Meulenkamp et al., (1979), Frydas et al., (1998), ten Veen and Postma, (1999).

The second group, belonging to the N120E (to N140E) trending in the order of km-scale faults, presents high angle surfaces and normal dip slip component. These faults mainly cut the older, preneogene and neogene rocks (Fig. 2, Location 10). However, tectonic movements on some fault surfaces may indicate that the corresponding episode started earlier, probably at the Latest Serravallian times. All these faults are intersected by N20-28E fault (Fig. 2, Locations 1, 5, 7) observed in abundance (ten Veen and Postma, 1999) in central Crete at the eastern side of Ida Mountains. Tectonic status at the location (10) corresponds to $\mathrm{N} 222^{\circ}$ extension which is similar to the Earliest Tortonian episode referred by ten Veen and Postma (1999).

The third and the fourth group belong to the N00E-N020E and to the N030-40E trending faults, respectively. Both groups show generally high angle surfaces $\left(70-80^{\circ}\right)$, except a small number of faults belonging to fourth group that show medium $\left(50-60^{\circ}\right)$ and normal dip slip component. The differentiation between the two groups is mainly based on the stress field $\left(\sigma_{3}=97^{\circ}\right.$ to $\left.123^{\circ}\right)$. These members deformed the older generations of faults (Fig. 2, Locations 1, 8, 9, 10) and are mainly related to the Middle and the Late Tortonian tectonic activity. At this point we have to refer that strike slip motion (Fig. 3) has also been indicated in two members of the third group. Similar strike slip mo- 
tion has been reported by ten Veen and Postma (1999) in the same period. These authors referred that the Late Tortonian to Early Messinian episode is marked by important tectonics, related to the beginning of N075E-orientated oblique slip. Faults, belonging to the N020E trending system, are bounding the Giouchta Mt. (Fig. 2, Locations 8,9) as it is also inferred by Fassoulas (2001). At the location (7) N10-20E fault postdates the older N110-112E trending structure while it is cut by a N160-165E fault (Fig. 2, location 6). It is also noteworthy, that ten Veen and Postma (1999) referred the strong vertical fault movement along N020E, including the Sitia Fault Zone, Ierapetra Fault Zone and the W Dikti Fault Zone.

The reactivation of normal faulting along the older, roughly E-W trending, extensional structures, during Early Messinian, characterized by a roughly dip slip component (close to the locations 2 and 10 in Fig. 2) is also supported by this work.

The fifth group of extensional structures includes the N040E to N060E trending faults showing high angle surfaces and normal dip slip component (Fig. 2, Locations 5, 12). These are moderate-scale NE-SW striking faults (Figure 3, column " 3 ") associated with the Pleistocene to recent times tectonic activity. At the location (12) in Figure 2, N050E trending faults formed small graben. However, the dextral lateral motion, referred by ten Veen and Postma (1999) for similar structures in the central and the eastern Crete, is not observed in this area.

The sixth group includes the youngest members, belonging to the N160E - N180E trending faults (Fig. 2, locations 4-4a, 5, 7, 8, 11). They present high angle surfaces and normal dip slip component, too. Especially, at the locations (5) and (5a) part of the flysch is trapped between two similar faults with significant vertical throw. Faults belonging to the N160E group intersect all the above-mentioned faults and are probably associated to the radial extension dominating in the southern Aegean area (Angelier, 1982). This group is also indicated in adjacent areas covered by Holocene sediments. Armijo et al. (1982) and Lyon-Caen et al. (1988), however, stated that at present Peloponnesus and Crete are dominated by approximately E-W extension and dip-slip movements along approximately $\mathrm{N}-\mathrm{S}$ orientated faults. Our work field data is in agreement with this. However, the last two groups could be equivalents to the episode "E" shown in Figure 3.

Moreover, we have no data, concerning the Late Miocene (Messinian) and Early Pliocene times extensional stress patterns, as no outcrops, dated at these time-periods, are present in the study area. Some data about the above-mentioned periods and related extensional stress fields, varying from WNW- ESE to ENE-WSW are indicating in the Figure 3 from adjacent areas (Axos - Anogia basin, paper under preparation).

Additionally, it is noted that our data are also in agreement with kinematics and structural data from the tectonic windows of eastern Crete and Dodecanese Islands (Kokkalas and Doutsos, 2004).

\section{Magnetic Data}

Figures 4a,b show the distribution of the mean low frequency measured magnetic susceptibility (LF), mean high frequency measured magnetic susceptibility (HF) and frequency dependent susceptibility (FD) in relation to normal faulting age. Low and high frequency magnetic properties are proportional and correspond to relative greater values for the Latest Serravalian - Early Tortonian faults. The frequency dependent susceptibility shows an inverse proportional relation to the fault age, except for the Early to Late Tortonian faults. At this point we have to refer that the Late Tortonian-Middle Messinian group corresponds to reactivation along the older, roughly E-W trending, extensional structures. The distribution of the low frequency and frequency dependent magnetic susceptibility is shown in the maps of Figures 6 and 


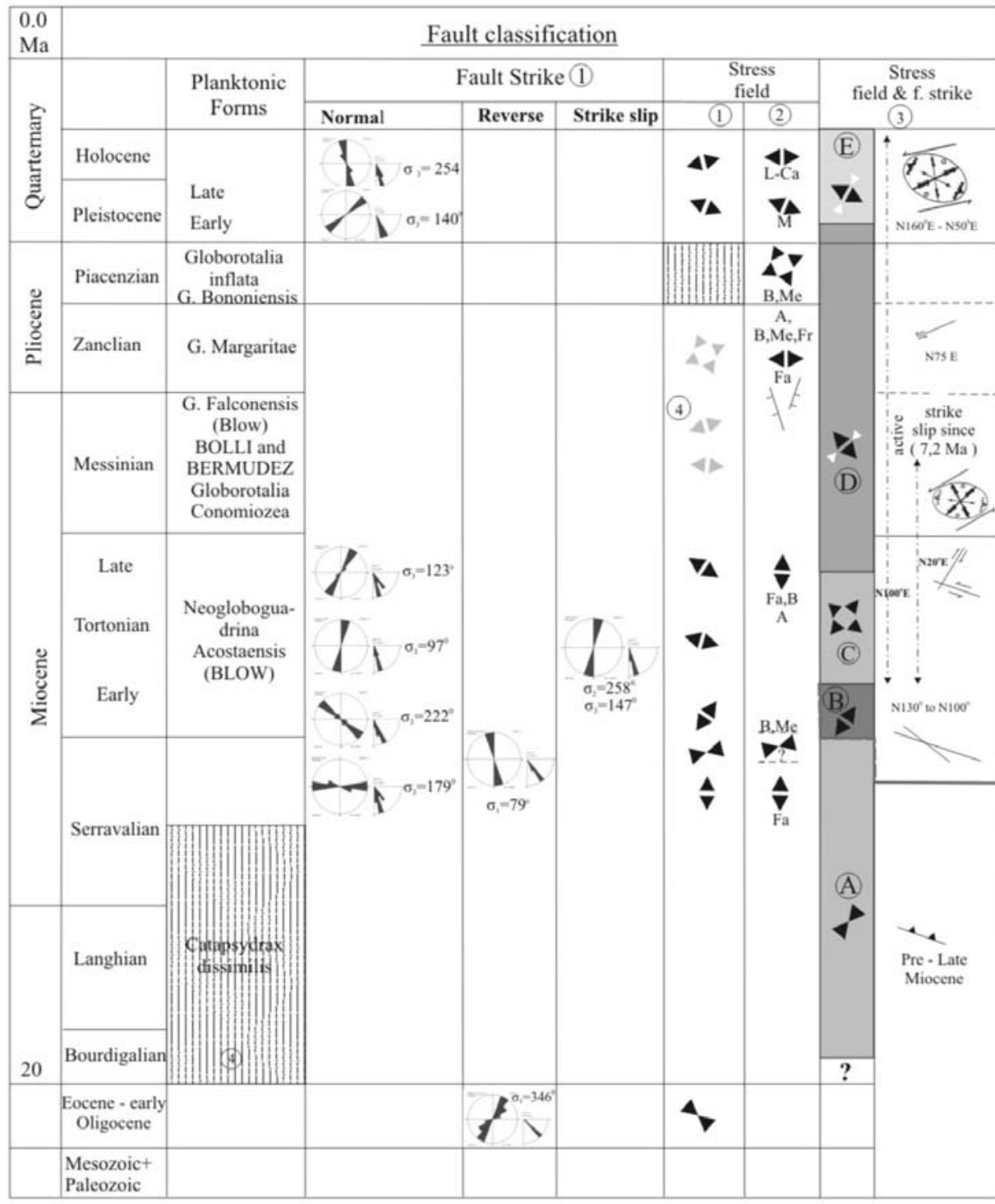

(1) Giouchtas Mt. (2) Central Crete : B - Benda (1974) (A) -Angelier (1979 a,b) Me-Meulenkamp (1979) M-Mercier (1981,89) L. Ca-Lyon - Cayen, (1988) Fr = Frydas (1998) Fa-Fassoulas (2001) (3) Central / Eastern Crete (ten Veen and Postma, 1999) Planktonic Forms by Tsaila - Monopolis St. (4) by authors et. al. ( article in preparation / Axos - Anogia basin)

Fig. 3: Fault classification in Giouchta Mt.

7. Relatively high values of the low frequency susceptibility observed in the whole area, demonstrating that the stratigraphy of the study area consists of Miocene sediments and Jurassic-Cretacoeus limestone. It has to be mentioned that at least two regions located in the top of Giouchta Mt. have been recognized as being functioned as sacred places in the ancient times and the corresponding intense anthropogenic activity influenced the distribution of magnetic susceptibility in the corresponding areas. A good correlation between faulting strike and LF as well FD magnetic susceptibility is generally observed (Fig. 5). 

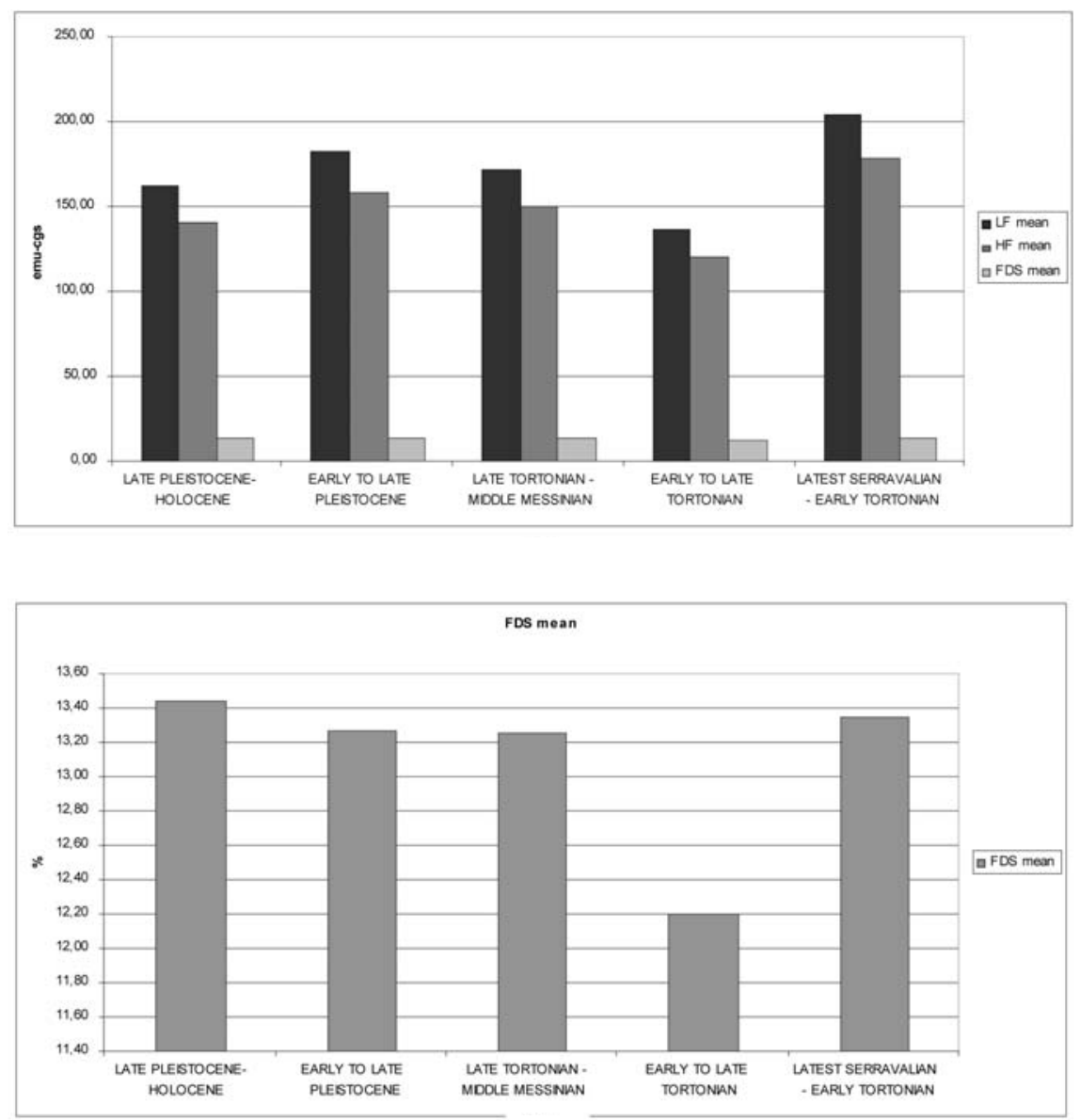

Fig. 4: Classification of the faults in relation to stratigraphy, mean of the magnetic properties, frequency dependent susceptibility.

\section{Conclusions}

Giouchta Mt. is an example of a pre-existing contraction structure that was deformed in later stages by normal faulting, produced by extensional episodes from latest Serravallian to sub recent times. These episodes indicate stress fields that influenced the area, with N-S trending direction in Late Serravallian times, via NE-SW in Latest Serravallian (?)-Early Tortonian, to WNW-ESE during Early to Middle Tortonian. The stress field changed to NW-SE in Late Tortonian to Early Pleistocene times and finally to ENE-WSW in Middle Pleistocene to sub recent time-period.

Moreover, the reactivation of normal faulting along the older, roughly E-W trending, extensional structures, during Early Messinian, is characterized by a dip slip component. Finally, strain direction changes to ENE-WSW during Middle Pleistocene to Holocene times.

Magnetic susceptibility is proved to be a useful tool for fault zone characterization. As a future work we plan to carry out thermomagnetic runs in air to the surface samples as well palaeomagnetic analyses in cores from holes dug deeply below the weathered crust. 


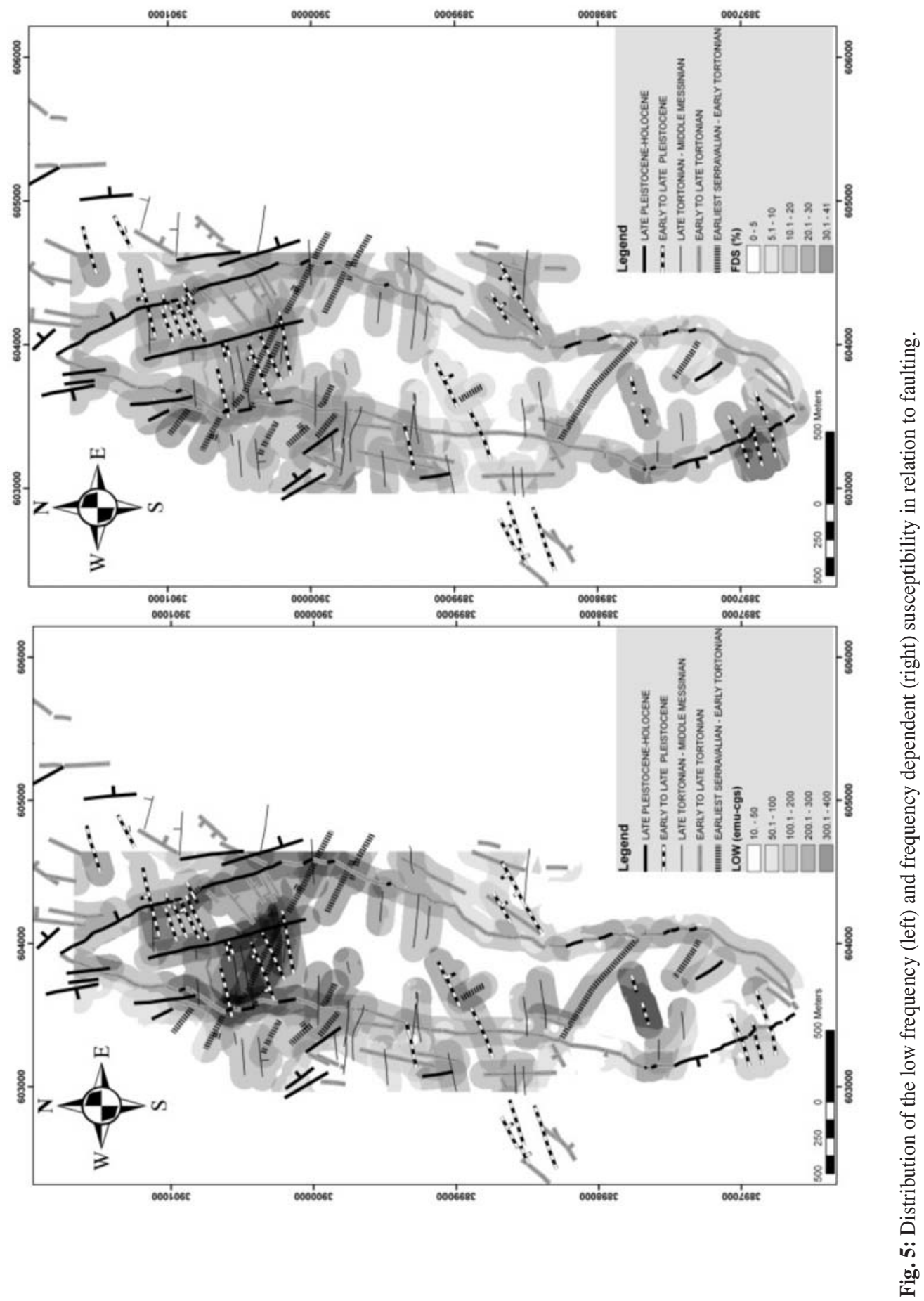




\section{References}

Alexander, J., Nichols, E.G. \& Leigh, S. 1990. The origins of marine conglomerate in the Indus foreland basin, Greece. Sed. Geol, 66, 243-254.

Angelier, J., 1979. Néotectonique de L'arc Egaen. Soc. Geol. Nord, Spec. Publ., 3.

Aubouin, J., 1959. Contribution a l'étude géologique de la Grèce septentrionale: le confins de l'Epire et de la Thessalie. Ann. Geol. Pays Hellen., 10, 1-484.

Armijo, R., Lyon-Caen, H., Papanastassiou, D., 1982. East-west extension and Holocene normal fault scarps in the Hellenic arc. Geology, 20, 491-494.

Benda, L., Meulenkamp, J.E., Zachariasse, W.J., 1974. Biostratigraphic correlations in the Eastern Mediterranean Neogene. 1. Correlation between planktonic foraminiferal, uvigerinid, sporomorphal and mammal zonations of the Cretan and Italian Neogene. Newsl. Stratigr., 3, 205-217.

Bonnefont, J.C., 1977. La néotectonique et sa traduction dans le paysage géomorphologique de l'Ile de Crete (Gre`ce). Rev. Gjogr. Phys. Gjol. Dyn., 14, 93-108.

Brunn, J-H., 1956. Contribution a l'étude géologique du Pinde et d' une partie de la Macédoine occidentale. Ann. Geol. Pays. Hellen., 13, 1-446.

Dercourt, J., 1964. Contribution a l'étude géologique d' un secteur du Péloponnèse occidental. Ann. Geol. Pays. Hellen., 15, 1-418.

Fassoulas, C., 2001. The tectonic development of a Neogene basin at the leading edge of the active European margin: the Heraklion basin, Crete, Greece. J. Geodyn., 31, 49-70.

Fleury, J., 1980. Les zones de Gavrovo - Tripolitsa et du Pinde - Olonos (Grèce continentale et Pèloponnése du Nord). Évolution d'une plateforme et d'un bassin dans leur carde alpin. Soc. Géol. Nord, 4, 1-651. Frydas, D. 1998. Plankton-Stratigraphie des Pliozans und unteren Pleistozans des SW-Peloponnes, Griechenland. Newsletters on Stratigraphy, 23, 91-108.

Geological map of Greece (1:50000), Epano Archanes sheet, IGME.

Kokkalas, S. and Doutsos, T., 2004. Kinematics and strain partitioning in the southeast Hellenides (Greece). Geol. J., 39, 121-140.

Lyon-Caen, H., Armijo, R., Drakapoulos, J., Baskoutas, J., Delibassis, N., Gaulon, R., Kouskouna, V., Latoussakis, J., Makropoulos, K., Papadimitrou, P., Papanastassiou, D., Pedotti, G., 1988. The 1986 Kalamata (south Peloponnesus) earthquake: detailed study of a normal fault, evidences for east-west extension in the Hellenic arc. J. Geophys. Res., 93, 14967-15000.

Mercier, J.L., 1981. Extensional-compressional tectonics associated with the Aegean Arc: comparison with the Andean Cordillera of south Peru - north Bolivia. Phil. Trans. R. Soc. London, A, 300, 337-355.

Mercier, J.L., Sorel, D., Vergely, P., Simeakis, K., 1989. Extensional tectonic regimes in the Aegean basins during the Cenozoic. Basin Res., 2, 49-71.

Meulenkamp, J.E., 1979. Field guide to the Neogene of Crete. Publishers. Dept. Geol.Pal. University of Athens, ser. A, 32, 1-31.

Meulenkamp, J.E., Wortel, M.J.R., Van Wamel, W.A., Spakman, W., Hoogerduyn Straating, N.E., 1988. On the Hellenic subduction zone and the geodynamic evolution of Crete since the late Middle Miocene. Tectonophysics, 146, 203-215.

Meulenkamp, J.E.,Van Der Zwaan, G.J., Van Wamel, W.A., 1994. On Late Miocene to Recent vertical motions in the Cretan segment of the Hellenic arc. Tectonophysics, 234, 53-72.

Ten Veen, J.H. and Postma, G., 1999. Neogene tectonics and basin fill patterns in the Hellenic outer-arc (Crete, Greece). Basin Research, 11, 223-241. 